\title{
Correction: A novel mutation in C5L2 gene was associated with hyperlipidemia and retinitis pigmentosa in a Chinese family
}

Ling-hui Qu, Xin Jin, Liang-mao Li, Shi-ying Li, Zheng-qin Yin ${ }^{*}$ and Han-ping Xie

\section{Correction}

After publication of this work [1], we noted that we inadvertently failed to include the complete list of all coauthors. The full list of authors has now been added.

Received: 30 June 2014 Accepted: 30 June 2014

Published: 8 July 2014

\section{Reference}

1. Qu LH, Jin X, Li LM, Li SY, Xie HP: A novel mutation in C5L2 gene was associated with hyperlipidemia and retinitis pigmentosa in a Chinese family. Lipids Health Dis 2014, 13:75.

- No space constraints or color figure charges

- Immediate publication on acceptance

- Inclusion in PubMed, CAS, Scopus and Google Scholar

- Research which is freely available for redistribution 